\title{
A farewell to arms: a deposit of human limbs and bodies at Bergheim, France, c. $4000 \mathrm{BC}$
}

Fanny Chenal ${ }^{1,2, *}$, Bertrand Perrin ${ }^{1, *}$, Hélène Barrand-Emam ${ }^{1,2}$ $\&$ Bruno Boulestin ${ }^{3}$

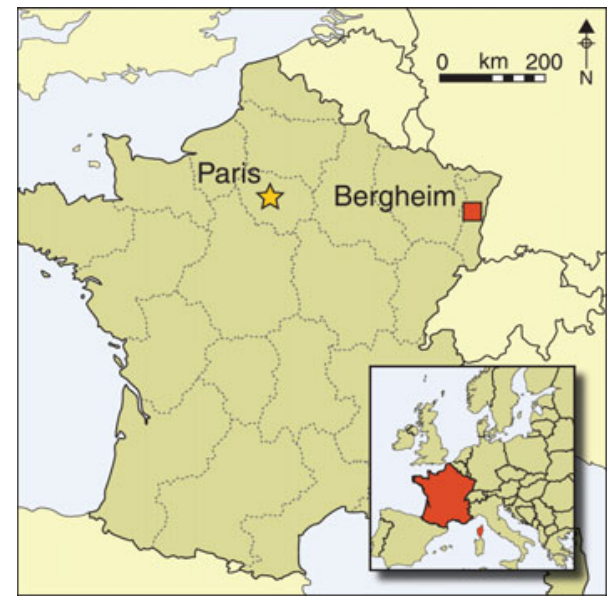

Between c. 4500 and 3500 BC, the deposition of human remains within circular pits was widespread throughout Central and Western Europe. Attempts at forming explanatory models for this practice have proven difficult due to the highly variable nature of these deposits. Recent excavations at Bergheim in Alsace have revealed a particularly unusual variant of this phenomenon featuring a number of amputated upper limbs. The evidence from this site challenges the simplicity of existing interpretations, and demands a more critical focus on the archaeological evidence for acts of systematic violence during this period.

Keywords: France, Late Neolithic, human remains, circular pits, amputation, violence

\section{Introduction}

Between c. 4500 and $3500 \mathrm{BC}$, one of the many ways to dispose of the dead throughout Central and Western Europe (from the Rhône valley to Slovakia and Hungary) was to deposit their remains in circular pits. Indeed, in some areas, this is the only form of corpse disposal that we know. The circular pits are commonly interpreted as disused silos. They may contain isolated bones, anatomical parts or complete or near complete skeletons. Deposits may comprise single or multiple individuals, sometimes accompanied by grave goods and animal remains, which may themselves be the subject of special deposits (for a recent review of the Upper Rhine region, see Lefranc et al. 2010). In Alsace, this practice is mainly

1 ANTEA-Archéologie, 11 rue de Zurich, F-68440 Habsheim, France (Email: fanny.chenal@inrap.fr; bertrand.perrin@antea-archeologie.com)

2 Université de Strasbourg, UMR 7044-ARCHIMÈDE, MISHA, 5 allée du Général Rouvillois, CS 50008, F-67083 Strasbourg Cedex, France

3 Université de Bordeaux, UMR 5199-PACEA-A3P, Anthropologie des populations passées et présentes, Allée Geoffroy-Saint-Hilaire, CS 50023, F-33615 Pessac Cedex, France

* Authors for correspondence 
associated with the Michelsberg and Munzingen cultures (c. 4100-3500 BC). It probably dates back, however, to the Bischheim culture (c.4500-4350 BC) and, more certainly, to the Upper Rhine western Bischheim Epi-Roessen group, also called BORS in French-formerly the Entzheim group-(c. 4300-4100 BC) (Jeunesse 2010; Lefranc et al. 2010: 63).

The first reference to these circular pit deposits dates to the end of the nineteenth century, one example being reported at the Michelsberg type-site in Untergrombach, Baden, Germany (Bonnet 1899). For a long time however, they have been dismissed by researchers as a mere epiphenomenon of little interest. Interpretation of these features began in earnest during the 1980s (Lichardus 1986; Schweitzer 1987), yet only in the last decade has it been demonstrated that the practices they represent were not marginal but rather part of a coherent tradition across an extensive area of Europe (Jeunesse 2010; Lefranc et al. 2010). This is due to an increasing number of discoveries, particularly in France, within the framework of rescue excavations. Several interpretations have been put forward, but even if the most recent studies agree on some of them, not one of which is totally satisfying. The example provided by a recent discovery at Bergheim, Alsace, brings remarkable and unique evidence to the debate.

The commune of Bergheim is located $50 \mathrm{~km}$ south-east of Strasburg, in the Haut-Rhin department, between the foothills of the Vosges Mountains and the Upper Rhine plain. A rescue excavation was carried out during the summer of 2012 by ANTEA-Archéologie over an area of approximately 2 ha. It revealed occupations from three distinct periods: a Linearbandkeramik village, a series of Late Neolithic silos and an area of silos from the beginning of the La Tène period. Of the 60 Late Neolithic silos, 14 have produced human bones (Figure $1 \&$ Table 1). These bones are isolated or correspond to anatomical parts or to complete individuals, a pattern that matches the general characteristics of deposits in circular pits found throughout the region at this time (Lefranc et al. 2010). Yet one silo, pit 157 , is utterly exceptional in its contents.

\section{Pit 157}

Pit 157 is $2 \mathrm{~m}$ deep and circular in plan with a diameter of $1.5 \mathrm{~m}$ at the surface, increasing to $1.9 \mathrm{~m}$ at $0.3 \mathrm{~m}$ above the base. It has yielded mostly human remains. The only artefacts clearly associated with these remains were an ornament made with the valve of a freshwater mussel, supposedly worn by individual number 4 , and an arrowhead, whose shape recalls the BORS types, found near the ribs of individual number 7. At the bottom of the pit, an unretouched block of sandstone, seemingly deposited intentionally, was also discovered (Figure 2). Faunal remains were limited to a fragment of pig mandible, also found at the bottom of the pit, and the skeletons of two hares. It was impossible to determine whether the hares were deposited deliberately or whether they accidentally fell into the feature. Two radiocarbon dates on femurs belonging to two different human individuals (numbers 7 and 1), the lowest and the highest stratigraphically, provide a chronological attribution,

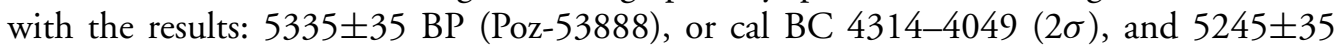

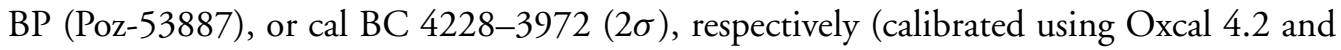
IntCal 13). These dates correspond to the BORS or the Early Michelsberg of the Upper Rhine region.

(C) Antiquity Publications Ltd, 2015 


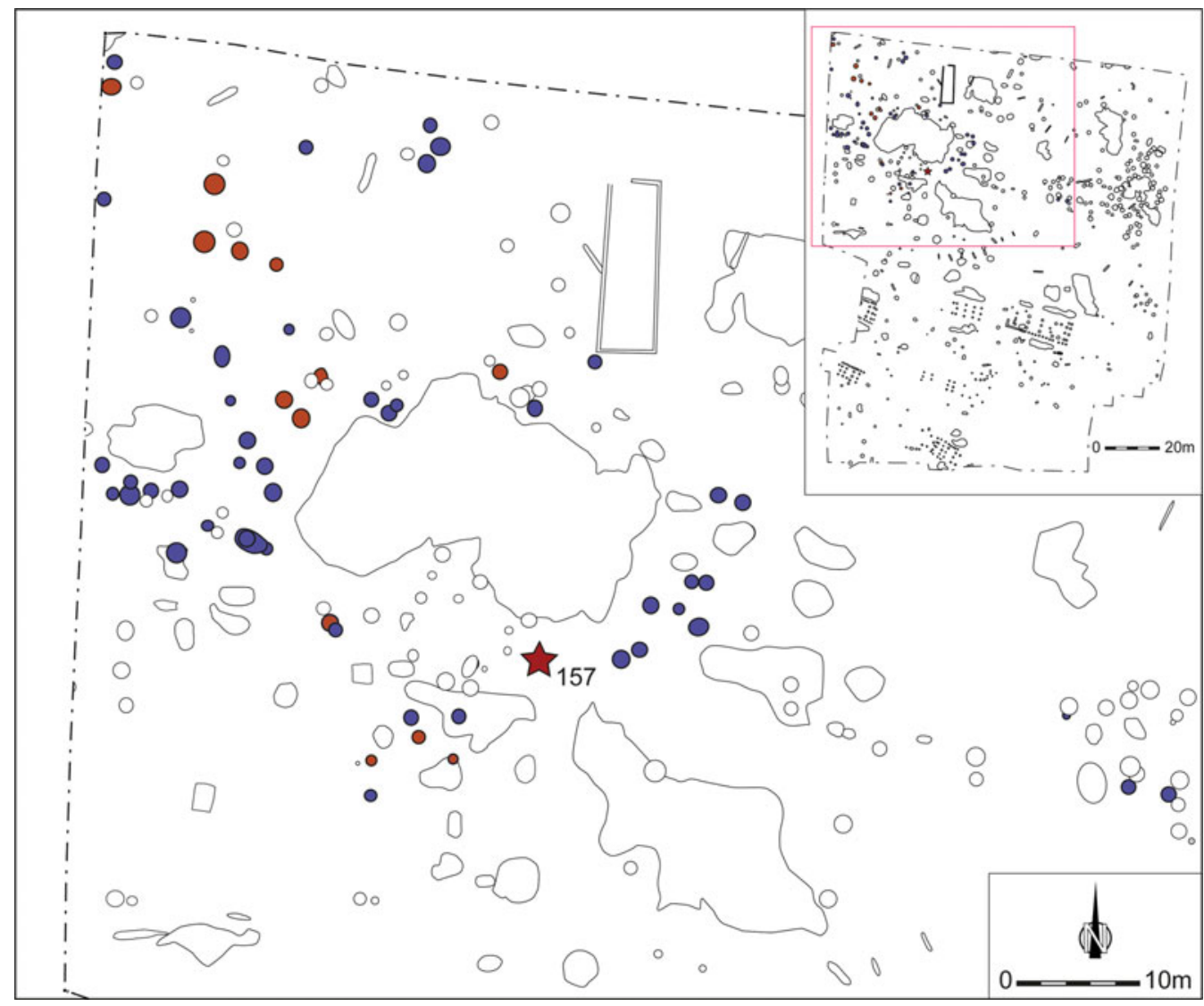

Figure 1. Plan of the Late Neolithic settlement area at Bergheim; inset shows location on the overall excavation map; coloured features represent Late Neolithic circular pits, with red indicating those containing human remains and blue for those without; the red star indicates the location of pit 157.

Through careful study of stratigraphy and taphonomy, it was possible to reconstruct the chronology of the deposits within the pit, thereby revealing complex deposition practices. The first deposit in the base of the pit comprised at least seven portions of left upper limbs, amputated through the arm and represented by seven humerii, seven radii, seven ulnas and the carpals, metacarpals and phalanges of at least five hands (Figure 2). Three elbow joints were still articulated at the time of discovery, as well as four radio-ulnar groups. Unless the anatomical connections were preserved intact through drying, smoking or some other form of preservation-a conceivable, yet unprovable, hypothesis-they demonstrate that these parts were deposited freshly after amputation. Other parts, notably the hands, the bones of which were completely scattered, had been disarticulated prior to deposition. This made the systematic reconstitution of the limbs for each individual impossible. Six of the limbs belonged to adults, or individuals of adult size, and the seventh belonged to a child or adolescent whose age is estimated to have been between 12 and 16 years (Scheuer \& Black 2000). A large number of the remains display evidence of modification, some relating to amputation, others to the cutting up of the arms and hands (see below). 


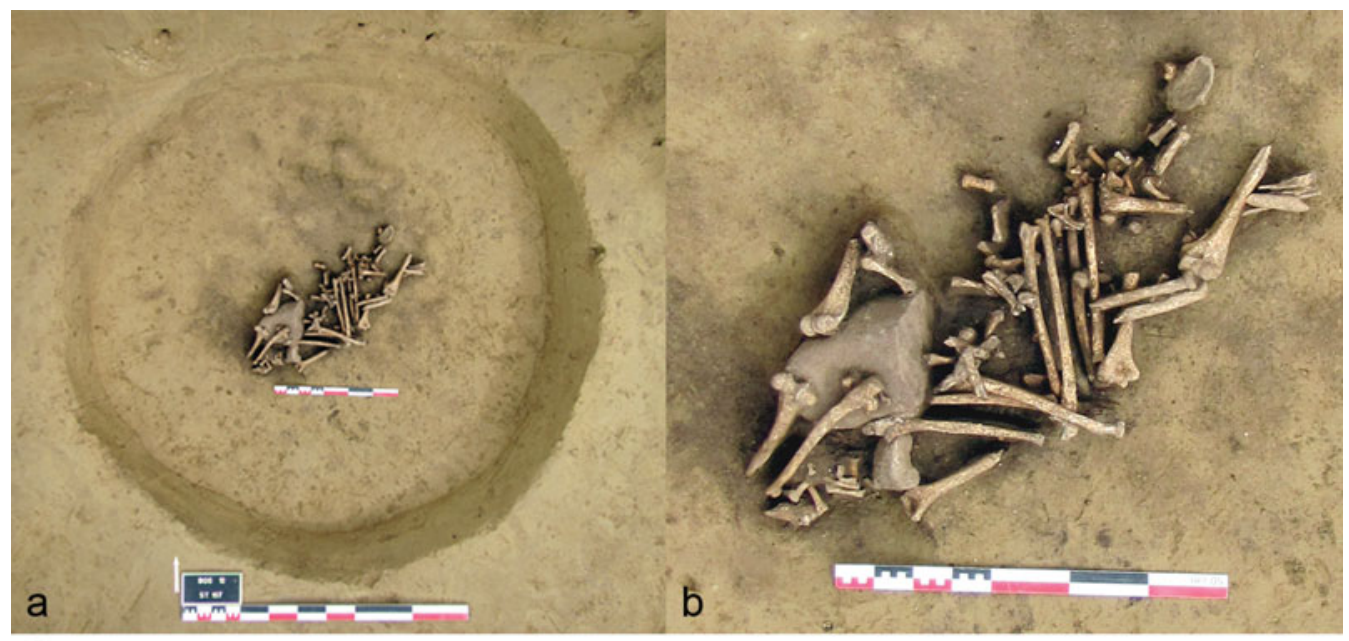

C

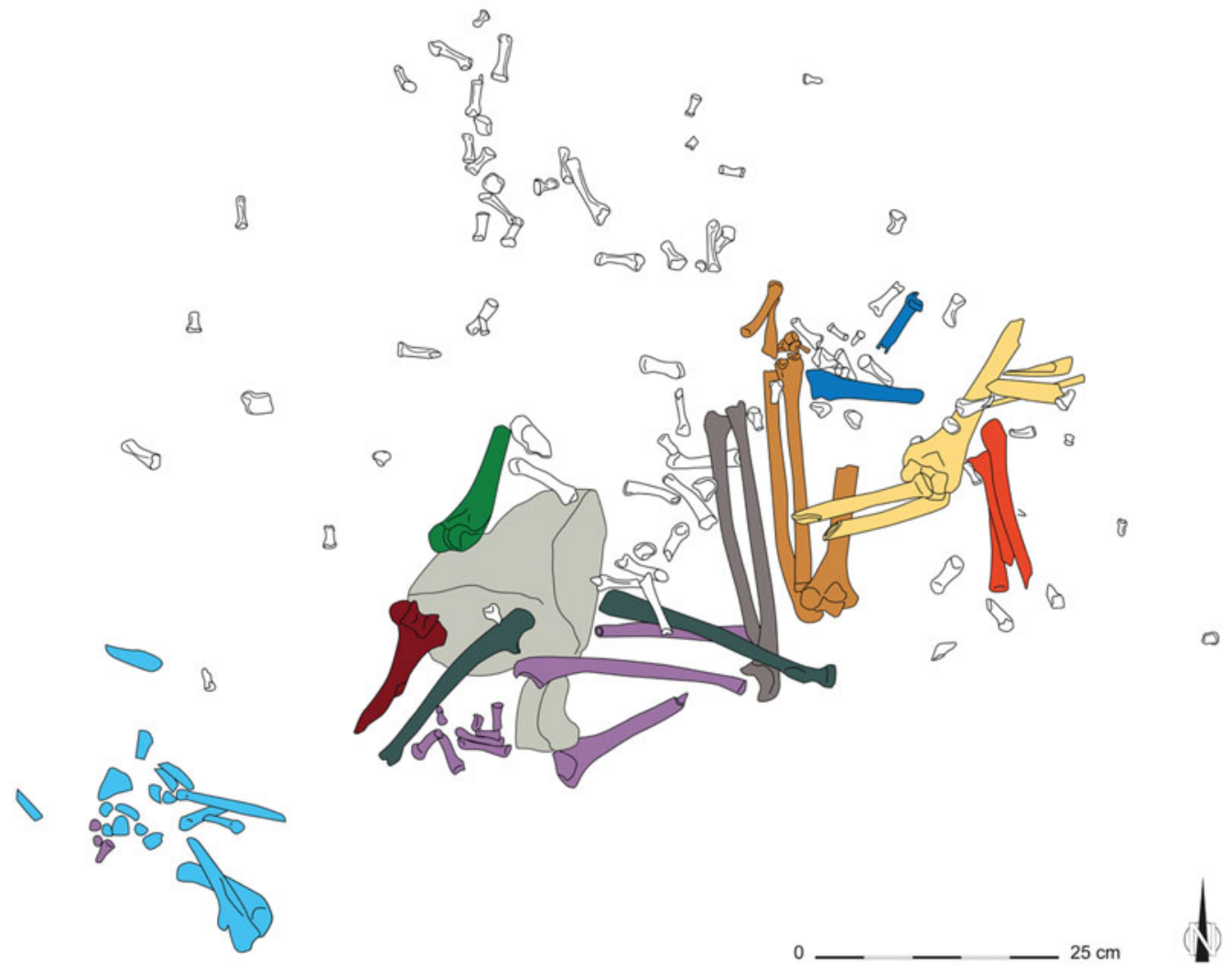

Figure 2. Overhead view of the left upper limbs deposit on the bottom of pit 157: a) the main heap at the centre of the pit; b) close-up in situ view; c) plan of all remains with bones of the same colour identified as belonging to the same individual.

(C) Antiquity Publications Ltd, 2015 
Table 1. Minimum number of individuals (MNI) and quantification of human corpses, anatomical parts and isolated bones in Late Neolithic pits containing human bones from Bergheim.

\begin{tabular}{|c|c|c|c|c|c|c|c|}
\hline \multirow[b]{3}{*}{$\begin{array}{c}\text { Pit } \\
\text { number }\end{array}$} & \multirow[b]{3}{*}{$\begin{array}{l}\text { Total } \\
\text { MNI }\end{array}$} & \multicolumn{6}{|c|}{ Number of: } \\
\hline & & \multicolumn{2}{|c|}{ Corpses } & \multicolumn{2}{|c|}{ Anatomical parts } & \multicolumn{2}{|c|}{ Isolated bones } \\
\hline & & $\begin{array}{l}\text { Adults } \\
(\geq 20)\end{array}$ & $\begin{array}{c}\text { Children } \\
(<20)\end{array}$ & $\begin{array}{l}\text { Adults or } \\
\text { adult size }\end{array}$ & Children & $\begin{array}{l}\text { Adults or } \\
\text { adult size }\end{array}$ & Children \\
\hline 2 & 5 & - & 5 & - & - & - & - \\
\hline 34 & 2 & 1 & 1 & - & - & - & - \\
\hline 36 & 1 & - & - & - & - & 1 & - \\
\hline 37 & 1 & - & - & - & - & 1 & - \\
\hline 57 & 1 & - & - & - & - & 4 & - \\
\hline 61 & 1 & - & - & - & - & - & 5 \\
\hline 79 & 1 & - & 1 & - & - & - & - \\
\hline 103 & 2 & - & 2 & - & - & - & - \\
\hline 118 & 2 & - & 1 & - & - & 2 & - \\
\hline 129 & 1 & - & 1 & - & - & - & - \\
\hline 157 & 15 & 4 & 4 & 6 & 1 & - & 1 \\
\hline 744 & 1 & - & 1 & - & - & - & - \\
\hline 746 & 1 & - & 1 & - & - & - & - \\
\hline 747 & 1 & 1 & - & - & - & - & - \\
\hline
\end{tabular}

The bodies of seven individuals, numbers $2-8$, as well as a fragment from the skull cap of an eighth, were placed in the pit directly overlying the deposit of upper limbs (Figure 3). The remains were sexed and aged according to the methods documented by Murail $e t$ al. (2005) and Ubelaker (1989: fig. 71) respectively. They belonged to three adults (two males and one female) and four children, whose age-range estimates are between 2 and 4, 3 and 5, 6 and 9 , and 10 and 13 . The cranial fragment belonged to a very young infant, probably less than a year old. The corpses had been piled up in a great variety of positions that one could describe as 'disordered': on their back, on their front or on their side, their limbs adopting haphazard postures and suggesting that they were discarded without care and without any deliberate attempt to organise them. The only exception to this is the juvenile aged between 3 and 5 (individual number 5), found on its left side in the foetal position, in a manner suggestive of a conventional burial, although this may be mere coincidence.

The lowest individual (number 7), a male between 30 and 59 years of age (Schmitt 2005), is distinguished by having had his left upper limb amputated through the arm. $\mathrm{He}$ also bears several marks of violent blows, notably on the skull, which probably correspond to his death (see below). None of the bones from the other six bodies display any modification. Unfortunately, we were unable to determine whether any of the amputated limbs in the underlying deposit belonged to individual 7. Attempts at establishing a link between his proximal humerus and one of the six mature distal portions of the same element were inconclusive, as were attempts at pairing the bones of his right upper limb with those of the amputated left upper limbs: we could attest neither an association nor a complete exclusion. 
Fanny Chenal et al.
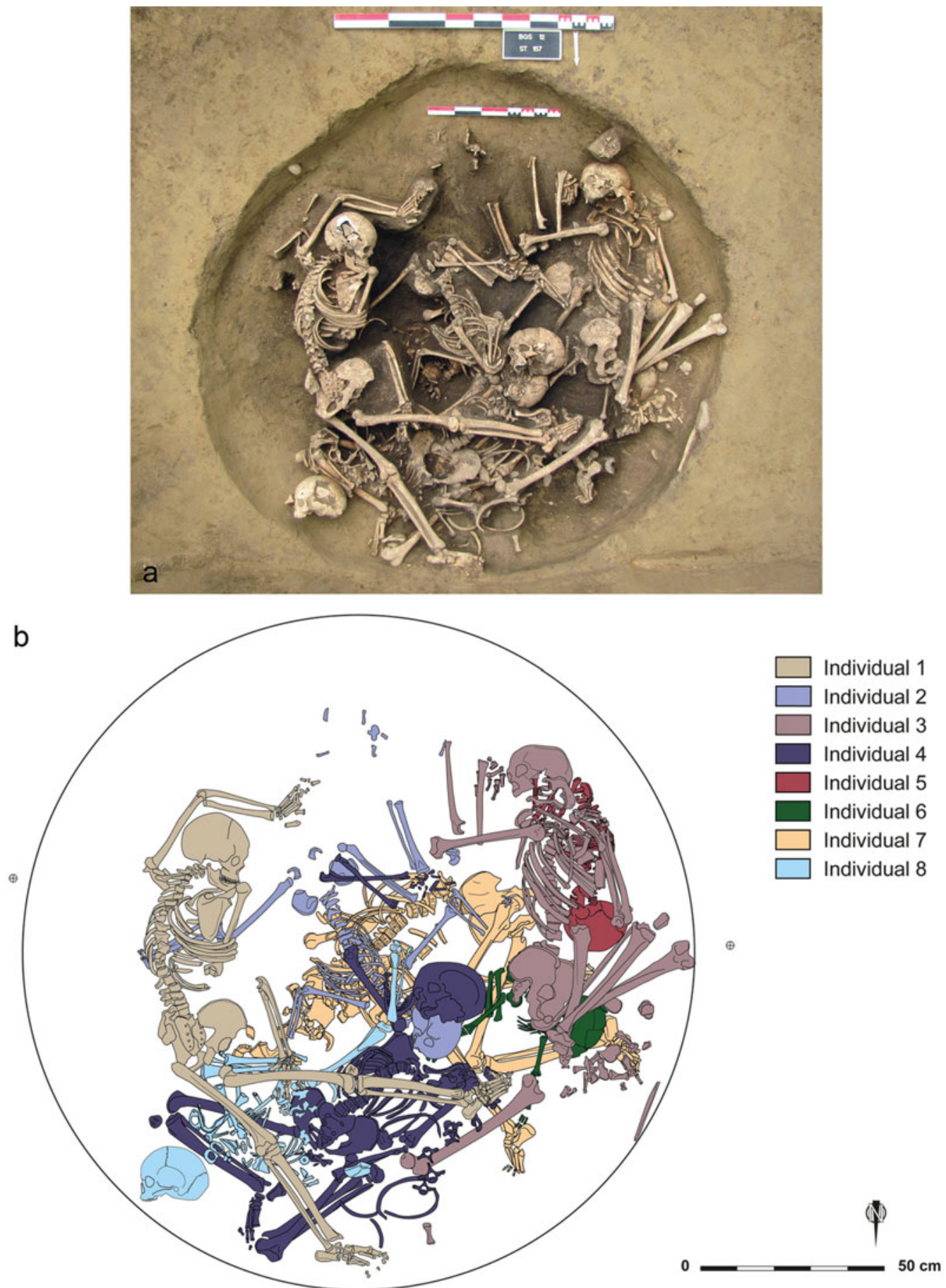

Figure 3. General view of pit 157 (a); and plan of the complete or almost complete bodies (b).

(C) Antiquity Publications Ltd, 2015 


\section{A farewell to arms}

The minimum number of individuals (MNI) for the lower part of the pit can therefore be set at 14, comprising 7 articulated bodies, at least another 6 left upper limbs-because we cannot exclude the possibility that one of the upper limbs belongs to individual number 7 - and a cranial fragment of a very young infant.

The upper limbs and complete individuals were either deposited simultaneously or over a very short time frame. They all are strictly in contact and labile joints have been preserved, which would have been disturbed if there had been any substantial lag in deposition (unless, for the limbs, there was special treatment prior to discard). Some post-depositional disturbances exist, but they affected the individuals in different ways depending on their stratigraphical location. Those situated at the top of the pit are the most severely disturbed, with bones displaced horizontally in the space external to the body. Those situated in the middle zone are only moderately disturbed, and those at the bottom have hardly moved at all. This vertical gradient of disturbance can be explained by the piling up of the bodies. Spaces form during the decomposition of a corpse into which the bones of overlying bodies may fall. The higher the bodies are placed on the pile, the greater the disturbances caused by this process. Nevertheless, this mechanism cannot account for the entirety of horizontal bone displacements among the uppermost individuals, leading us to believe that the pit was not filled in immediately after the bodies were deposited, but rather remained open long enough for at least partial decomposition to have been possible. This theory is supported by the presence of a naturally deposited sedimentary layer $0.1 \mathrm{~m}$ deep that covers the remains.

Above this sedimentary layer, an eighth body, that of an adult female, was introduced within the pit, also in a haphazard position (Figure 3, individual number 1). The excellent preservation of the connections corroborates the fact that compaction of the underlying levels had already taken place by the time this corpse was deposited, and that it decomposed in a filled space and was hence covered immediately by the final fill of the pit. No modifications have been observed on the bones of this final skeleton, nor indeed on any of the human remains from the other pits at Bergheim.

\section{Evidence of violence}

The upper limbs from the basal deposit display numerous bone modifications. Some of them relate to amputation: firstly, the fractures of the humeral shafts, which show all the characteristics of fresh bone fractures (Villa \& Mahieu 1991; Boulestin 1999) (Figure 4); and secondly, often multiple associated chop marks (Figures 4a \& c, 5). These marks sometimes cover a substantial portion of the shaft and are probably also partly related to the cutting away of soft tissue. A few cut marks left by finer tools used with a slicing motion may also relate to this action (Figure 6). Some other fractures appear to have no associated chop marks. Amputations were thus probably performed by violent blows inflicted with an implement such as an axe that would have cut through soft tissue and broken the bone. A knife may have been used to finish cutting through any remaining tissue.

Other modifications on the upper limbs show that they underwent much more complex treatments. Fresh bone fractures and cut marks are apparent on the forearms (Figures $7 \&$ 8), metacarpals and phalanges (Figures $8 \& 9$ ). The intention behind these modifications is unclear. The scattered hand bones at the bottom of the pit suggest that the hands were 


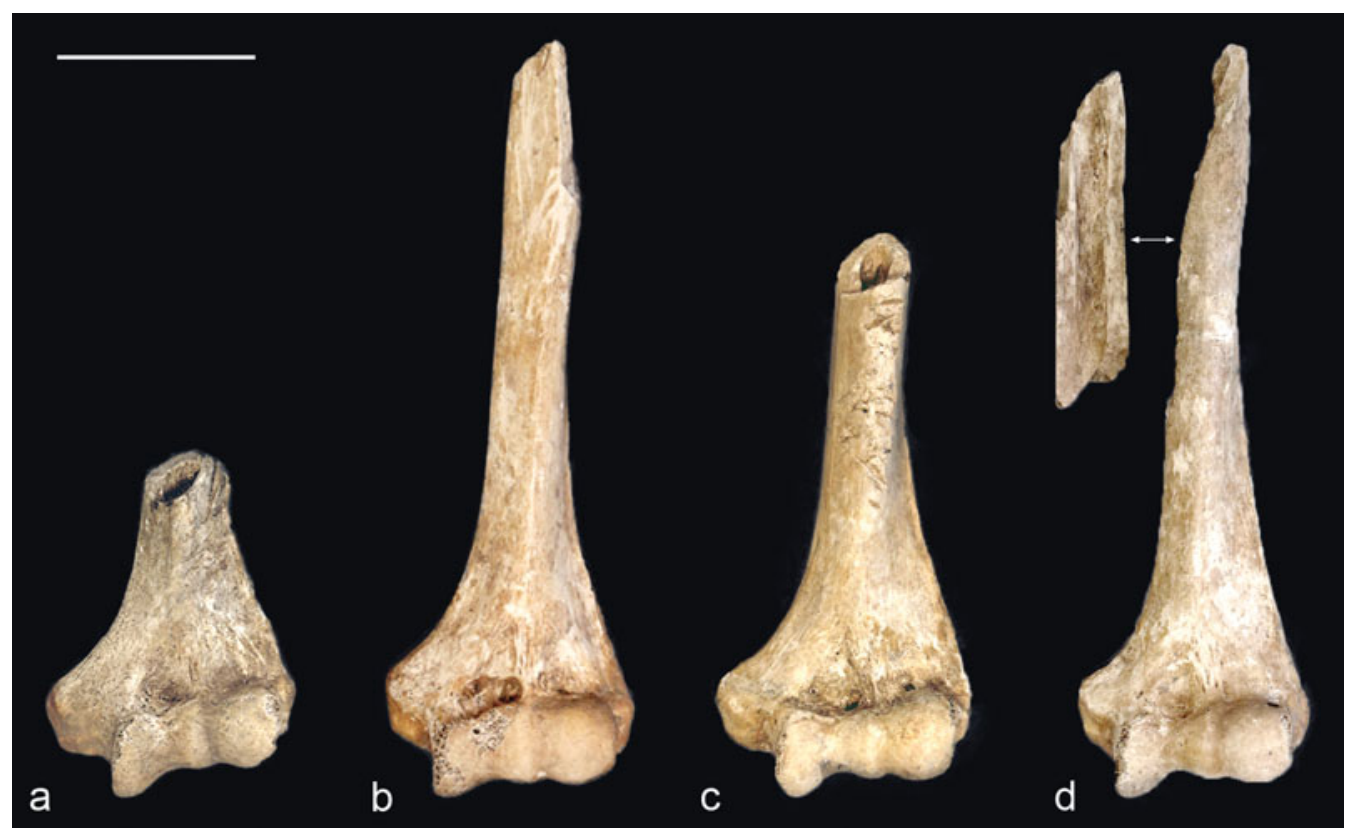

Figure 4. Examples of fresh bone fractures on left humeral shafts (scale-bar $=50 \mathrm{~mm})$.

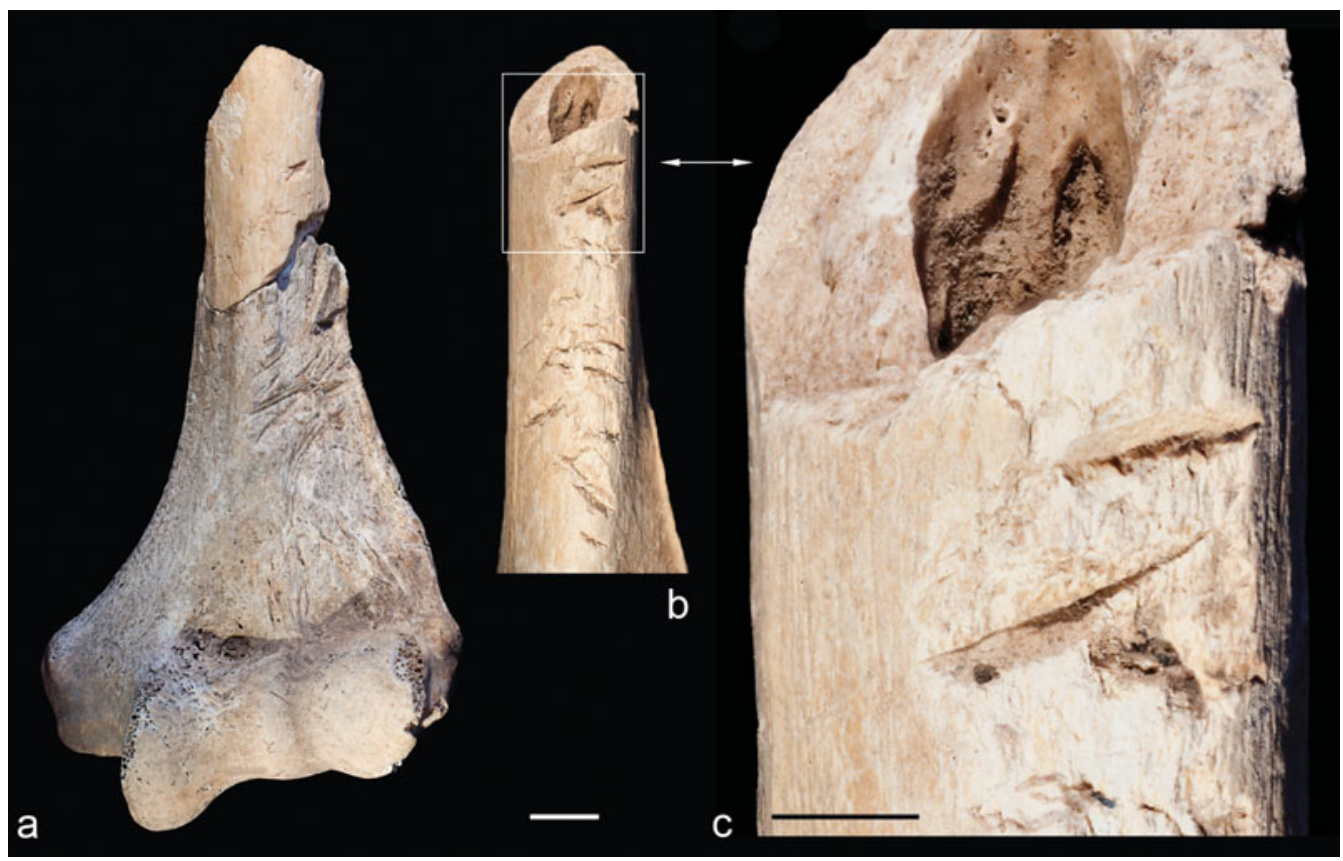

Figure 5. Examples of chop marks on left humeral shafts (scale-bar $=10 \mathrm{~mm}$; black bar $=5 \mathrm{~mm})$.

(C) Antiquity Publications Ltd, 2015 
deliberately cut into pieces, although this interpretation does not easily apply to all upper limbs, as numerous joints and a great number of small splinters were still articulated at the

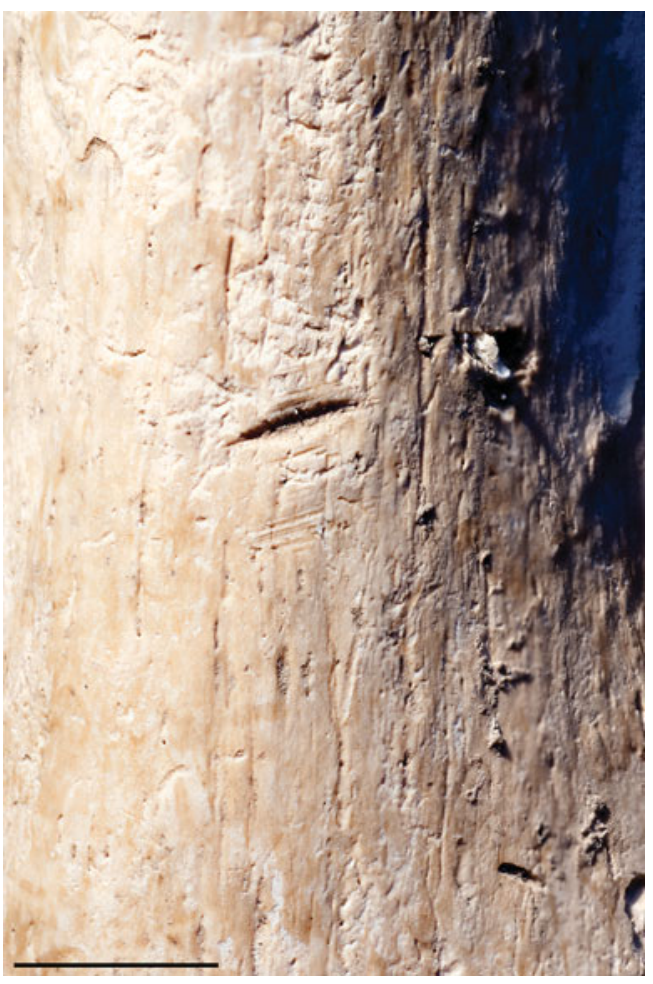

Figure 6. Cut marks on a left humeral shaft (scale-bar $=$ $5 \mathrm{~mm}$ ). indeed correspond to an execution. Other fresh bone fractures were noted on the left clavicle and scapula, and testify to another blow dealt at shoulder level. Three fragments of left rib also show evidence of peeling, possibly related to a thoracic blunt impact, although the presence of a cut mark on one of them also suggests the use of a cutting implement (Figure 11). Finally, the left arm was amputated through its proximal third. Although no tool mark is visible, a spiral fracture shows that the severing of the humerus resulted from a violent blow to the limb (Figure 12).

\section{Discussion}

Late Neolithic circular pits containing human deposits have been noted since the end of the nineteenth century, but raised little interest until the 1980s. Various interpretations have since been proposed that broadly conform to one of two opposing propositions. For some researchers, the great variety of the deposits found in these pits-in this case interpreted without exception as disused silos-means that they cannot be considered genuine burials (Nickel 1997). These researchers conclude that the deposition of human remains in circular pits was a marginal practice concerning individuals deemed unworthy of a normal funerary rite or of any funerary rite at all. Conversely, others such as Lichardus (1986) 


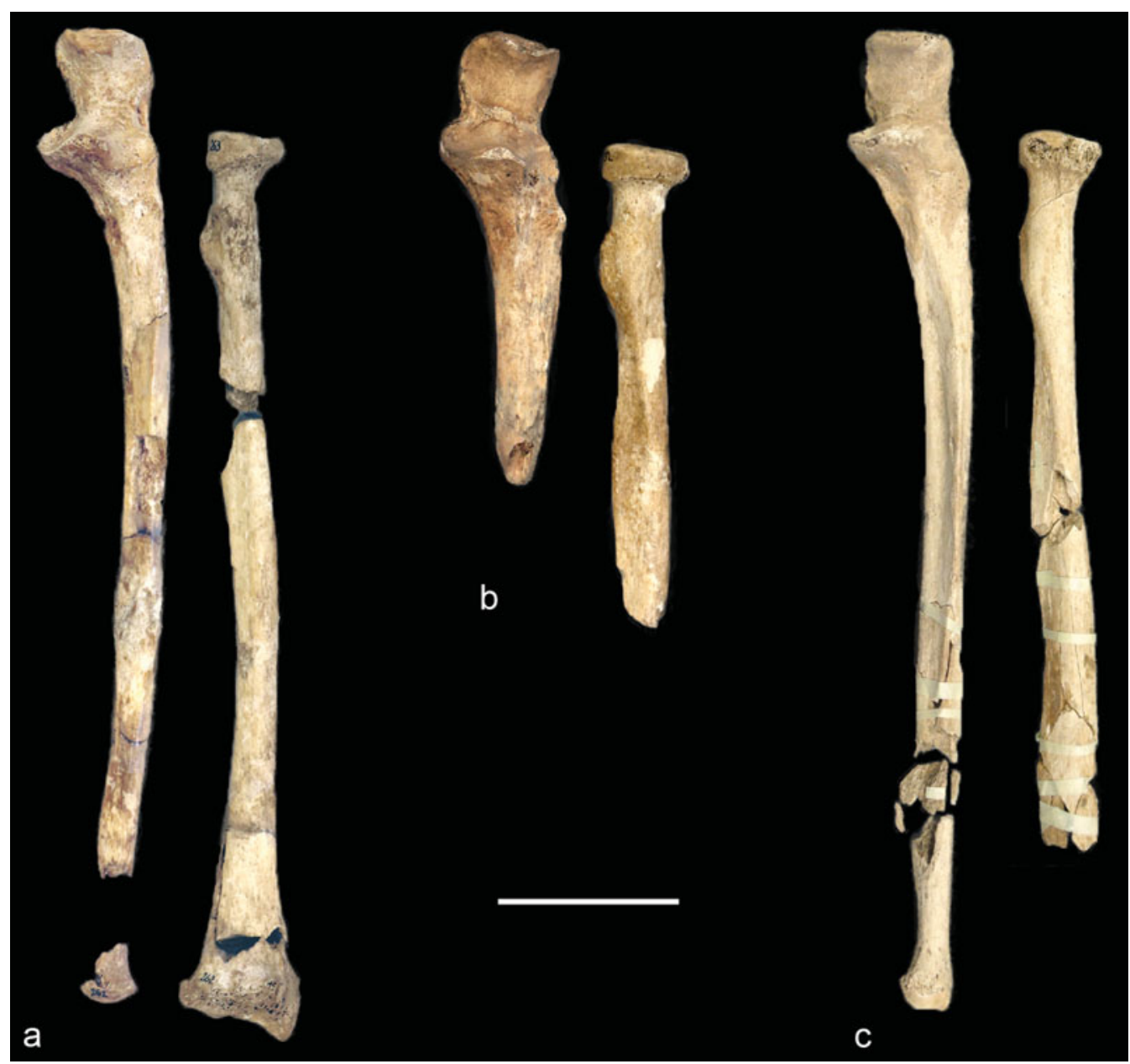

Figure 7. Examples of fresh bone fractures on the left forearm bones (scale-bar $=50 \mathrm{~mm})$.

and Schweitzer (1987) believe that these deposits represent genuine funerary practices, and furthermore that the pits were dug specifically for this purpose. In the absence of supporting evidence for either case, it is unclear which proposition is more probable of the two.

Observations by Alain Beeching and colleagues at sites in the Rhône Valley, notably Les Moulins at Saint-Paul-Trois-Châteaux and Le Gournier at Montélimar, provided the first real support for the funerary hypothesis. They also led to new avenues of investigation. These researchers noted the recurring opposition, in one and the same pit, between an individual termed as 'exceptional'-buried flexed on the side in the central part of the pit and accompanied by grave goods — and others described as 'secondary' (Beeching 1991: 337; Crubézy 1991). This observation led Beeching cautiously to suggest that these secondary individuals were 'accompanying dead' (Beeching 1991: 337). The idea was further developed (C) Antiquity Publications Ltd, 2015 
by Jeunesse, who showed that this pattern of asymmetry was to be found throughout the entire area, from the Rhône Valley to Central Europe between 4500 and 3500 BC

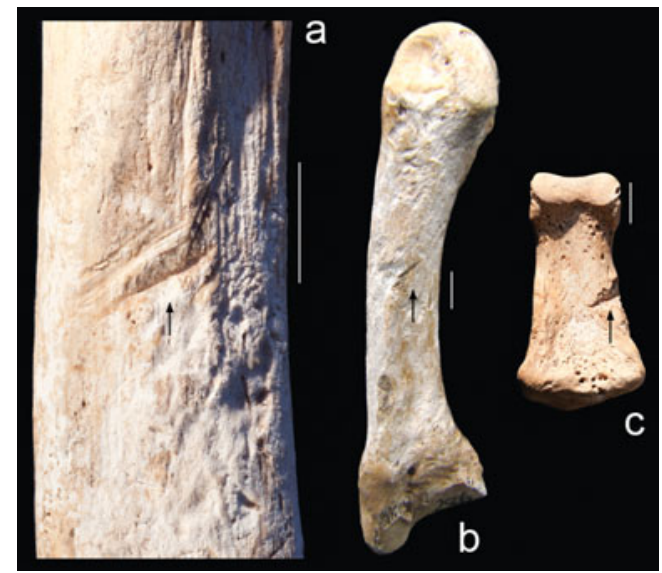

Figure 8. Cut marks on a left ulna (a), a third left metacarpal (b) and a left-hand middle phalanx (c) (scalebars $=5 \mathrm{~mm})$.
(Jeunesse 2010). In many cases, a single pit features multiple asymmetrical deposits, with one individual displayed in a so-called conventional or regular position (flexed on the side), accompanied by one or more individuals in haphazard positions, seemingly deposited without regard or any apparent rule. This repetitive pattern attests to a homogeneous and coherent phenomenon, both from the chronological and geographical points of view. The dating evidence from these sites testifies to a cultural movement from West to East, and southwards from Alsace or Bavaria.

The recurrence of this depositional pattern in the archaeological record also enables us to confirm that this was a regular practice, and reinforces the idea that it was truly funerary in nature. Within this framework, asymmetry is still in a rather consensual way interpreted as a practice of 'accompanying dead' (Baray \& Boulestin 2010), as characterised by Testart (2004), namely the killing of devoted servants or dependent relatives following the death of a high-ranking figure. Hence, asymmetry expresses the existence of a hierarchy among the dead that mirrors that among the living. For the Neolithic period, the most probable interpretation of dead bodies in a haphazard position is that of slaves killed at their master's death (Testart et al. 2010). Although this practice has often been labelled an act of 'sacrifice', we must stress that it is radically different both in its nature and its social implications-primarily because this is not a religious practice, in that it does not consist of an offering to supernatural beings (Testart 2004: 29-34).

Debate about the circular pit deposits from the Late Neolithic has continued more recently with the publication of a review of the evidence from the Upper Rhine region (Lefranc et al. 2010). Furthermore, a CNRS Research Group (GDR) led by Christian Jeunesse (the results of which remain as yet unpublished) has examined the phenomenon on a European scale. Both studies reassessed the homogeneity and coherence of this practice of deposition, and suggest that the accompanying dead model remains to date the best available to explain at least some aspects of the data. Nevertheless, it does not explain all of them, as only a small fraction of the deposits involve multiple contemporary interments, with one individual in a conventional position and others in haphazard positions. The model also fails to account for the numerous pits that contain only individuals belonging to the second category, which are still sometimes associated with high-value objects (Lefranc et al. 2012). Thus, it appears to be incomplete. This observation led Lefranc et al. to consider other interpretations, including sacrifice sensu stricto (offerings to supernatural entities) and the deliberate destruction of prestige goods, in a manner similar to the potlatch (Lefranc et al. 2010: 86-87; 2012:

(C) Antiquity Publications Ltd, 2015 


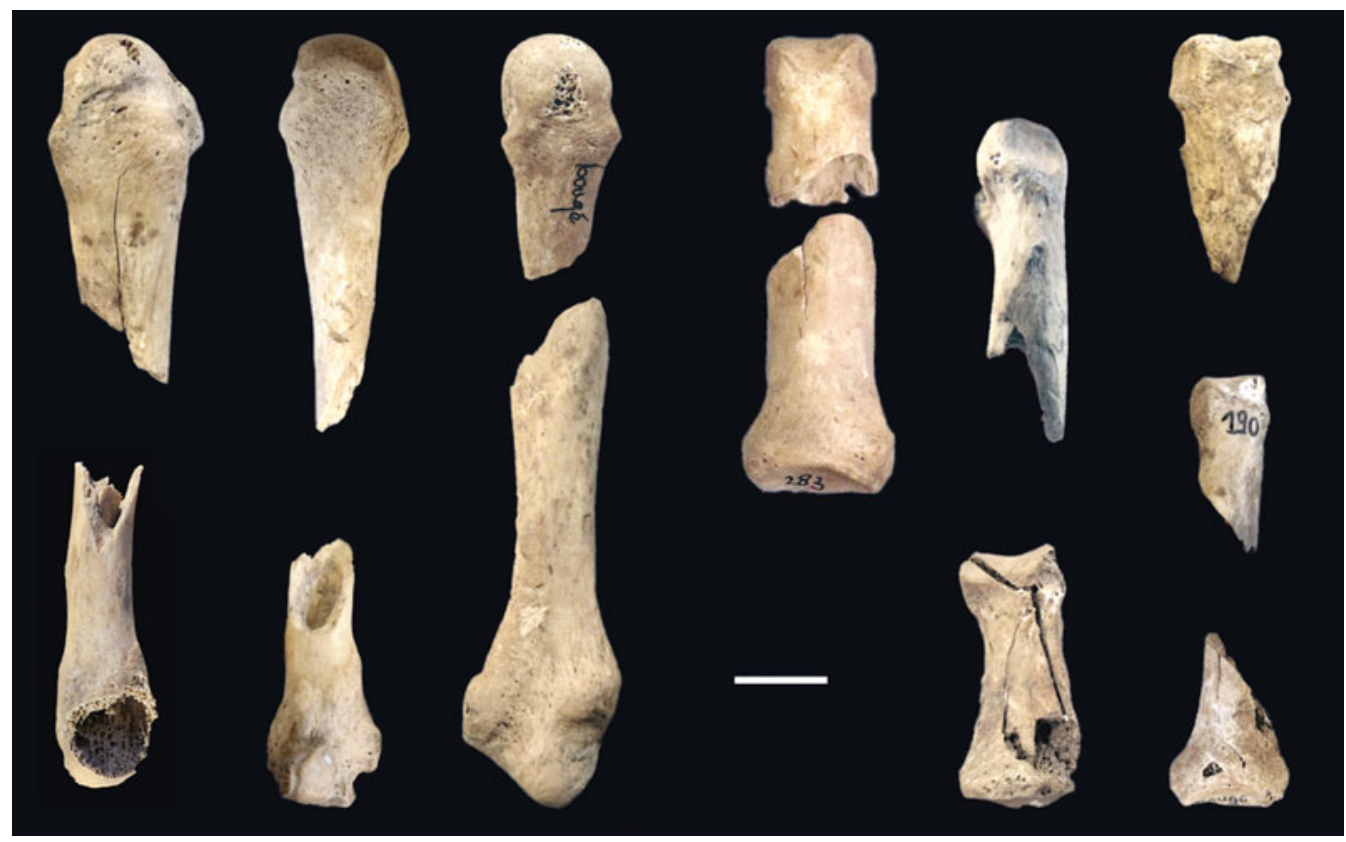

Figure 9. Examples of fresh bone fractures on left metacarpals (left) and hand phalanges (right) (scale-bar $=10 \mathrm{~mm}$ ).

725-27). It remains difficult, however, to see how these various explanations, pertaining to different fields_-funerary and non-funerary—could be interconnected.

\section{Bergheim pit 157: interpreting and integrating the models}

What do we learn from pit 157 in particular? Above all, its contents show clear evidence of armed violence. First, the archaeologically simultaneous death of seven individuals (individual number 1 is excluded from this account), assumed by their simultaneous burial, is not expected within a natural mortality profile (Boulestin 2008). This suggests that, excluding the possibility of starvation or an epidemic, these individuals must have been killed. Second, individual number 7 exhibits indisputable signs of violent blows to the head, which are probably related to his execution. Finally, the amputation of the left upper limbs displays features testifying to particularly violent acts rather than surgical practice. These amputations present the strongest evidence to support our interpretation of violence and make the most significant contribution to the debate. Indeed, they can fall only into one of two categories: judicial (intra-group violence) or war-like (inter-group armed violence). Historically, the amputation of various body parts has been used as a form of criminal punishment by many societies. Usually, only the extremities of the limbs were amputated, i.e. hands or feet, but that may not always have been the case. For the Bergheim pit, the hypothesis of judicial violence cannot be refuted by the exclusive presence of left arms or their number, given that they may be the result of a particular rite of collective punishment, or by the coexistence of amputation and killing, as the condemned individuals may have been tortured beforehand or as part of their execution. Nevertheless, other arguments dispute (C) Antiquity Publications Ltd, 2015 


\section{A farewell to arms}

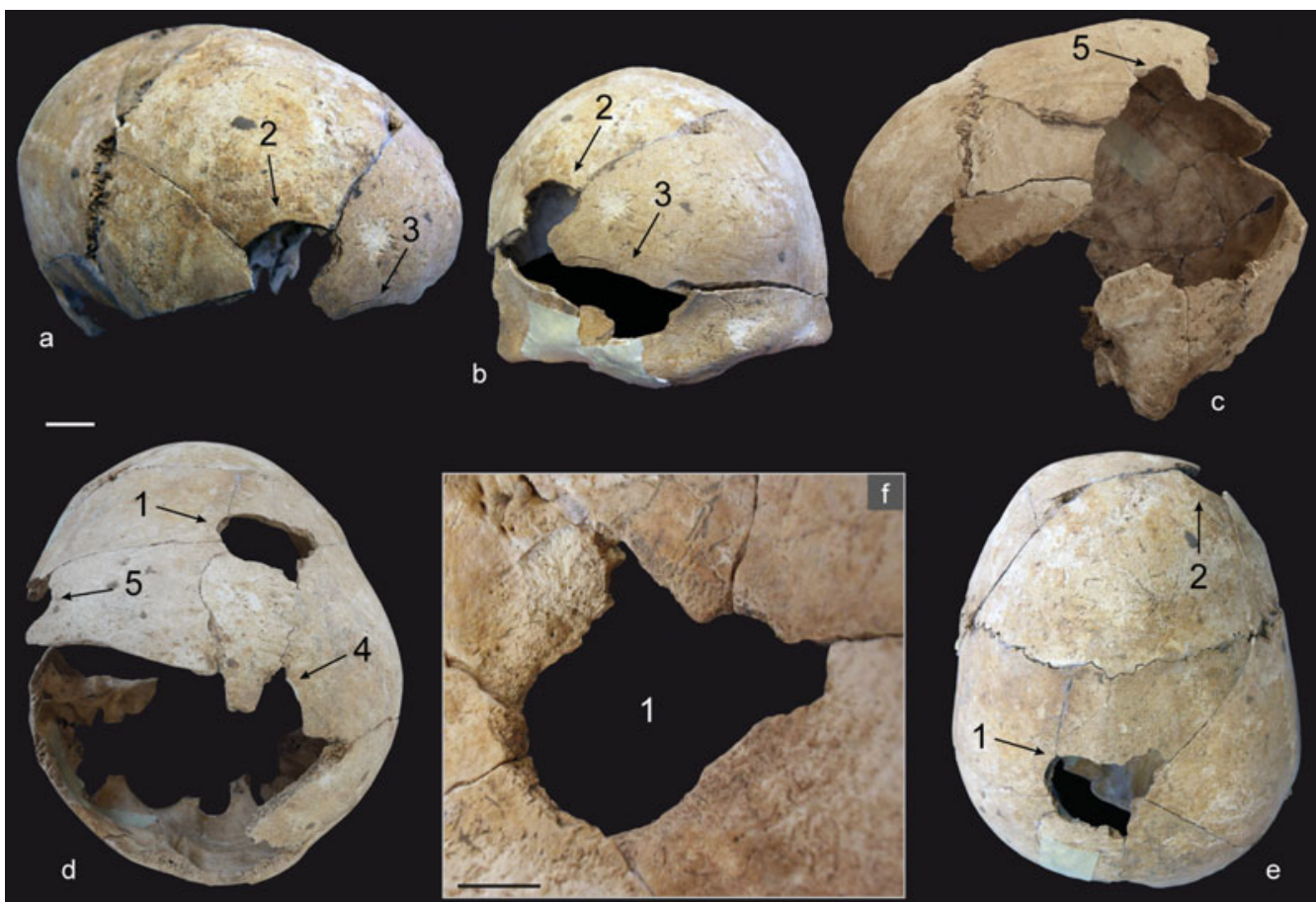

ปี
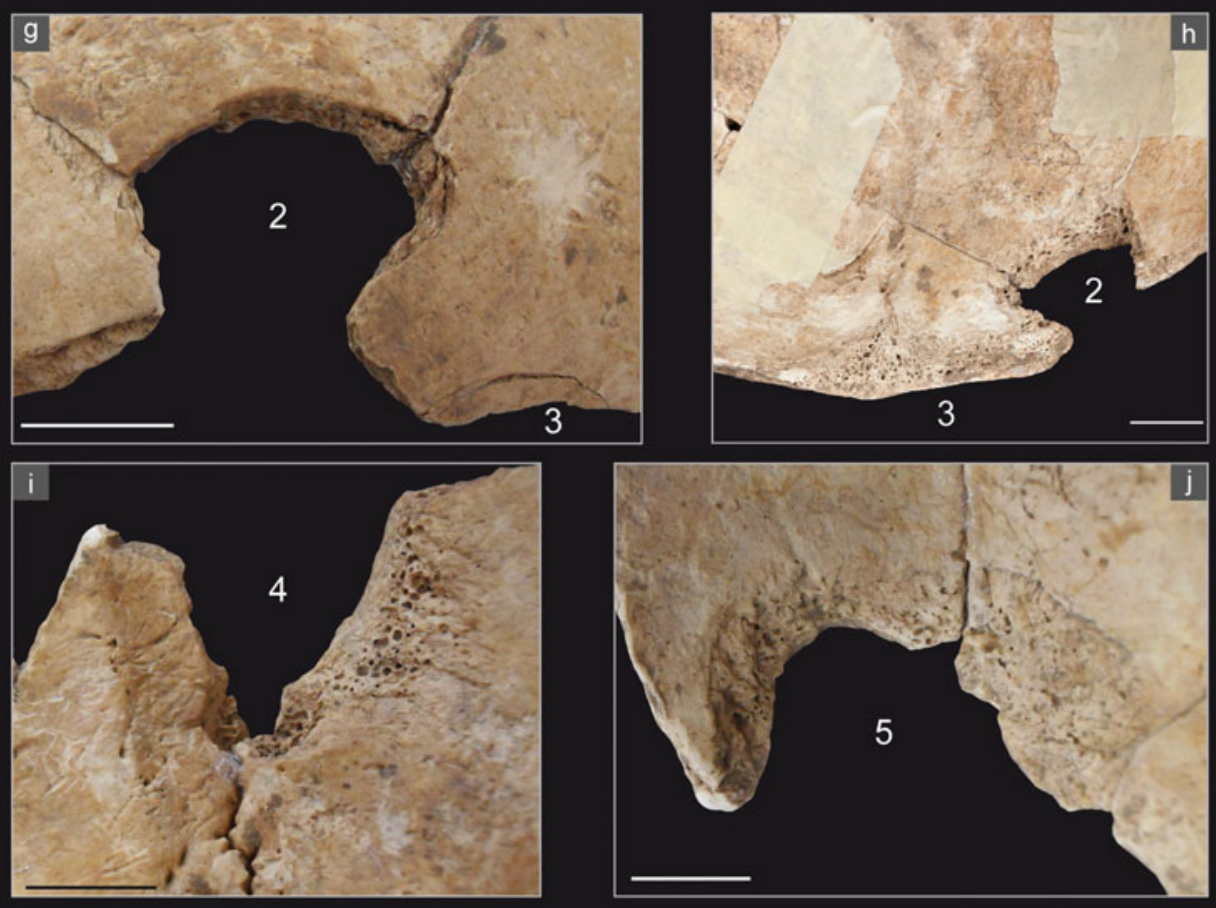

Figure 10. Impact points on the neurocranium of individual number 7 (1-5): a) right lateral; b) anterior; $c$ ) left lateral; d) posterosuperior; e) superior; $f), h-j$ ) endocranial details; and $g$ ) exocranial detail (scale-bars $=10 \mathrm{~mm}$ ).

(C) Antiquity Publications Ltd, 2015 


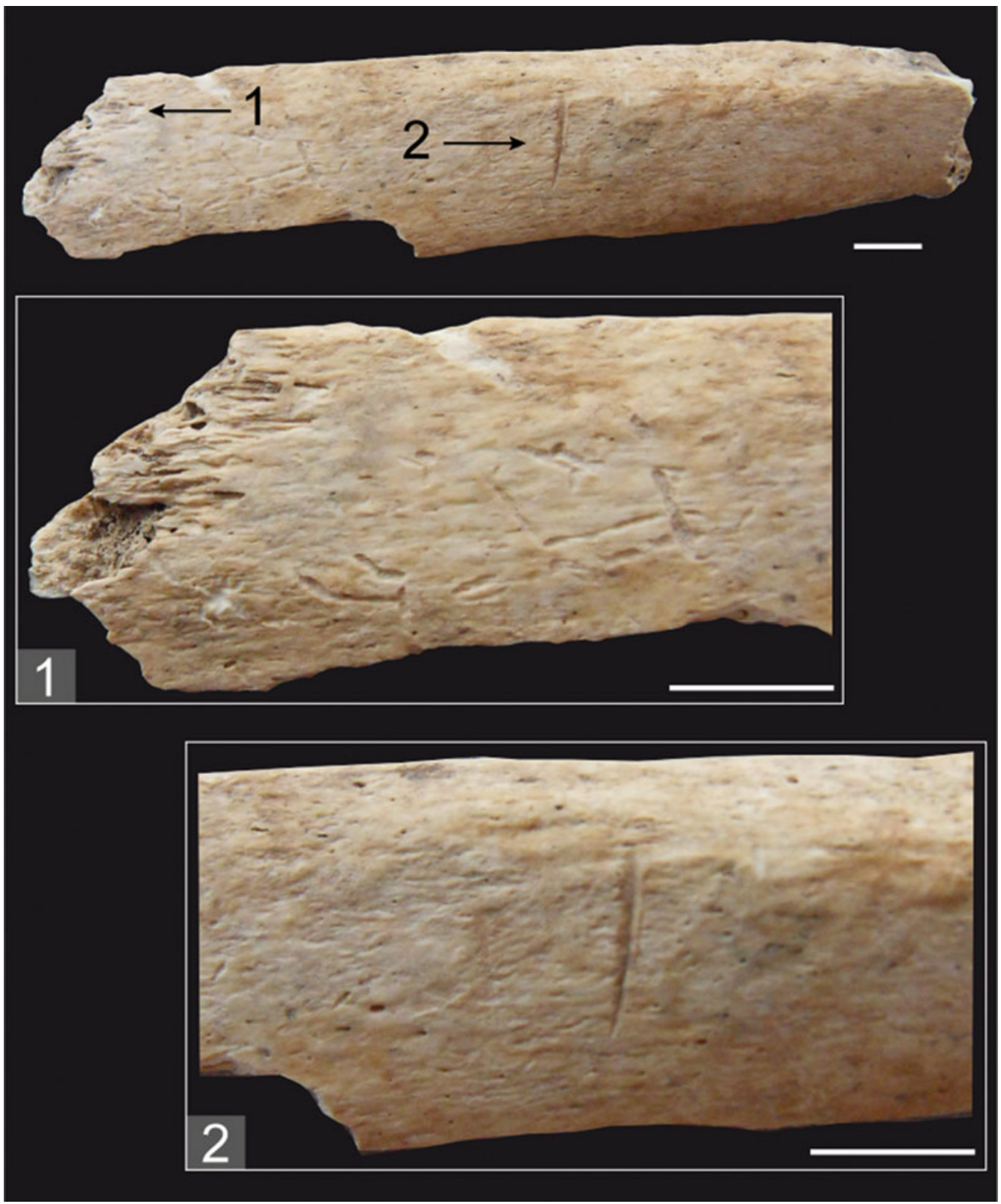

Figure 11. Fragment of a left rib of individual number 7 showing peeling (1) and a cut mark (2) (scale-bars $=5 \mathrm{~mm}$ ).

this hypothesis. Neither the fact that limbs underwent additional treatments — such as the cutting and disjointing of the hands - nor that they were put in a seemingly organised deposit, rather than simply discarded as with waste, seem a probable result of criminal sanctions.

(C) Antiquity Publications Ltd, 2015 


\section{A farewell to arms}

War-like practices offer a more convincing interpretation, with three possibilities: the amputations could correspond to post-mortem mutilations (intended either to offend the

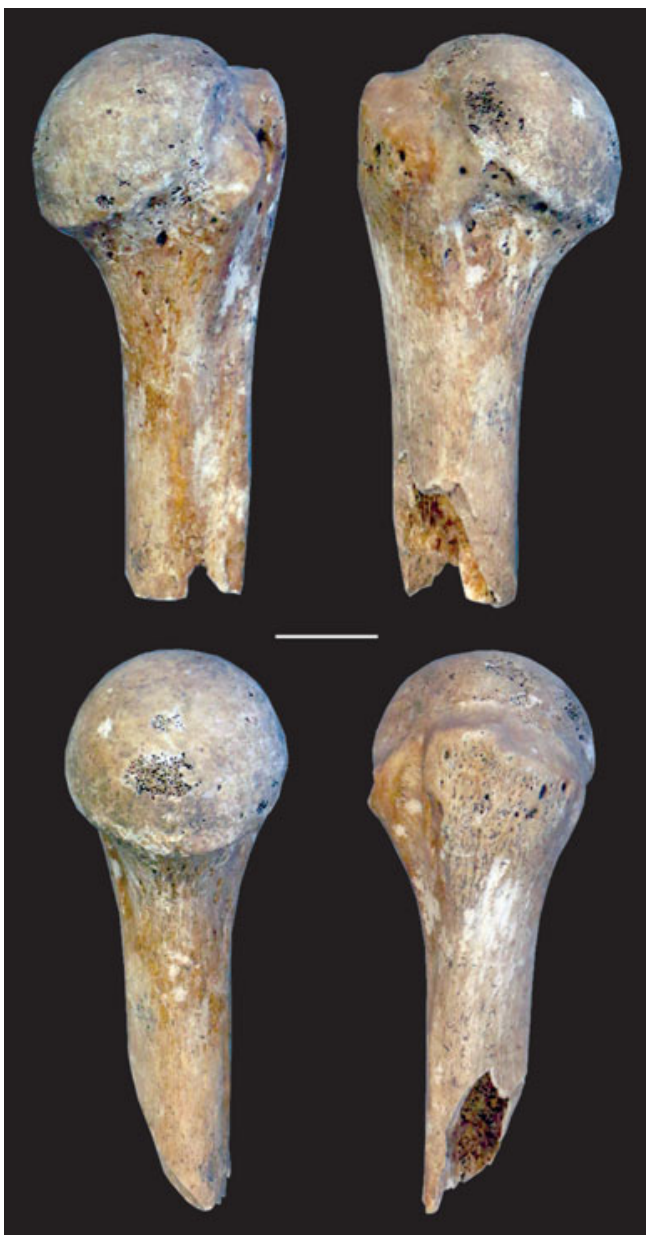

Figure 12. Green bone fracture of the left humeral shaft of individual number 7 corresponding to the amputation of the arm (scale-bar $=20 \mathrm{~mm})$. dead or intimidate the living), torture or the taking of trophies. This last practice in particular was documented by Jacques Le Moyne de Morgues while observing the American Timucua Indians in Florida in the sixteenth century. The description he gives of it resonates with the scenario proposed at Bergheim: "They also are accustomed, after a battle, to cut off with these reed knives the arms of the dead near the shoulders, and their legs near the hips, breaking the bones, when laid bare, with a club" (Le Moyne 1875: description of illustration 15) (Figure 13). Mention should also be made of the arm interpreted as a trophy that was discovered in a burial at the Ward Site in Kentucky (Mensforth 2007: 236-37 \& fig. 9.6).

The evidence from pit 157 undoubtedly testifies to armed violence, and the amputated arms, most probably trophies, are suggestive of an act of war. The presence of women and children in the pit does not go against this hypothesis: they may have been victims of raids, killed on the scene of the confrontation or captured and executed afterwardsalthough women and children were often enslaved, they were also sometimes tortured and killed (Knowles 1940). Whether they were victims of warfare or the recipients of judicial punishment, the case supports the idea that the haphazardly deposited individuals were either dependants or excluded individuals.

Integrating the data into different interpretative models of accompanying dead, the destruction of prestige goods or sacrificial rites, is not straightforward. The Bergheim case shows that the first of these models is incomplete. The only individual in a conventional position in the deposit was a three- to five-year-old child, and it is hard to argue that they were a figure of central importance in this arrangement (an assumption that itself would carry significant implications), and thus that the pit was actually a grave. Furthermore, it is difficult to explain the amputated arms within any funerary model. It is even more difficult, however, to see how these arms would be consistent with the destruction of prestige goods. 


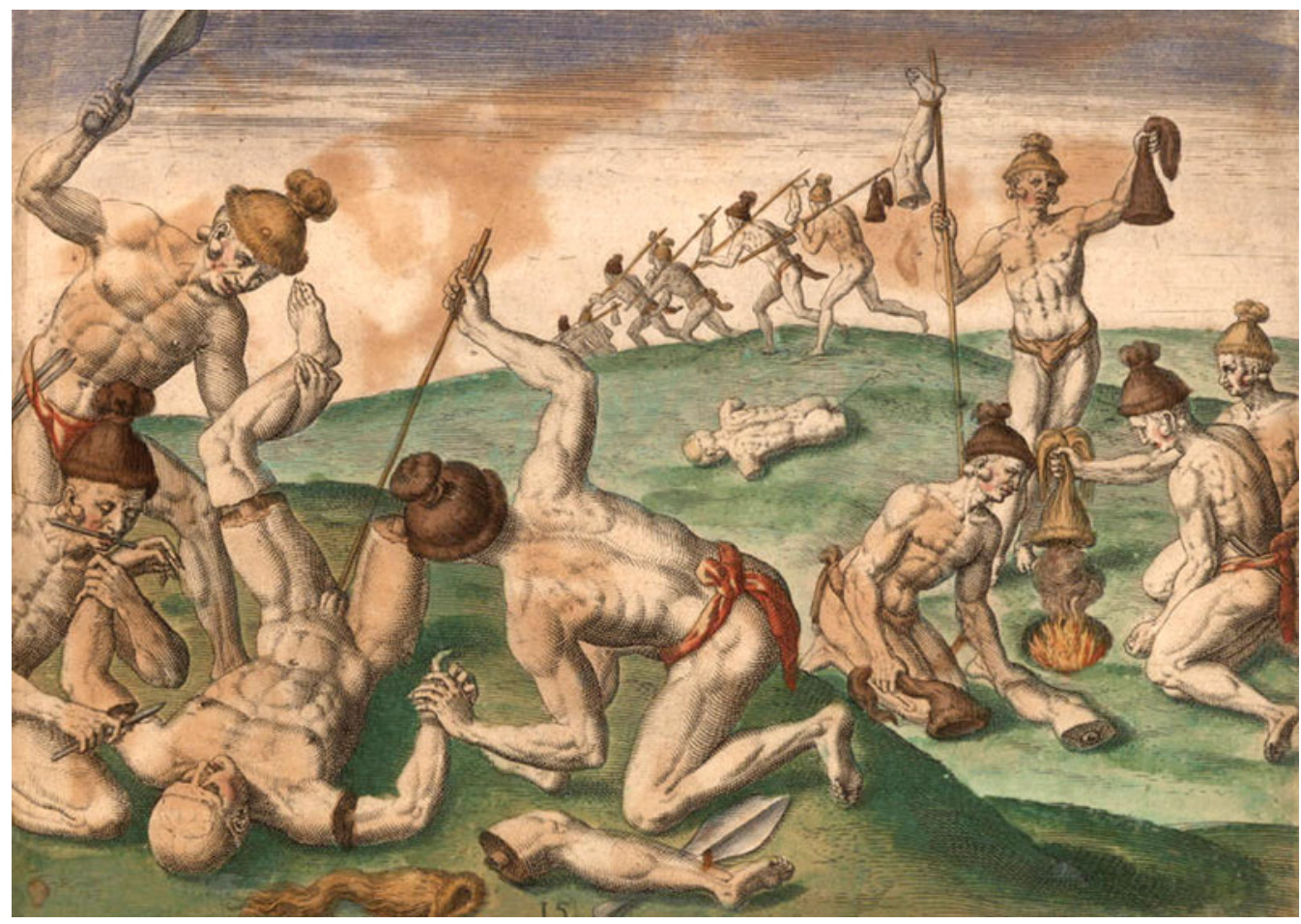

Figure 13. 'How Outina's men treated the slain of the enemy': scene showing the amputation of limbs to be taken as trophies (engraving 15, published by Theodore de Bry, after an original drawing by Jacques Le Moyne de Morgues, in Brevis narratio eorum quae in Florida Americae provincia Gallis acciderunt [1591]).

Killing one's slaves may indeed constitute a display of wealth, as was practised during funeral potlatch on the Northwest Coast of North America (MacLeod 1929: 106-11), but it seems questionable to consider that upper limbs alone would have expressed some kind of wealth. The amputated arms also pose a problem for the sacrifice model. They oblige us to suppose that they represent offerings to gods, as in any sacrifice, but this is difficult to reconcile with the trophy hypothesis, as trophies are not regarded as offerings (Testart 2012: 446). The sacrifice model is even less compatible with the hypotheses of mutilation and torture. Consequently, it remains problematical to integrate pit 157 within a general interpretative model for circular pit deposits, whatever it might be.

\section{Conclusion}

Pit 157 represents clear evidence of what was probably an act of inter-group armed violence, that is to say 'war', although the true nature of these practices remains difficult to understand. Interpreting this unique case is not easy, as, to our knowledge, no other example of amputation, or even of isolated articulated limbs, has ever been recorded for the Late Neolithic. It should not, however, be cast aside as an anomaly. As part of a wider phenomenon of circular pit deposits, whose unity and coherence, both chronologically and geographically,

(C) Antiquity Publications Ltd, 2015 


\section{A farewell to arms}

are taken for granted, it should not be excluded a priori from broader interpretative models. Indeed, unusual cases such as this are arguably the most important for evaluating existing interpretations. To date, none of the three current models-accompanying the dead, the destruction of prestige goods or sacrifice-satisfactorily accommodate the Bergheim data, and a reliable and complete model for explaining circular pit deposits is yet to emerge.

A more thorough evaluation of the evidence for violence in this region during the Late Neolithic, mostly documented for the Michelsberg culture, is required. Other examples of violent death have been recorded in circular pit deposits; for instance, at HeidelbergHandschuhsheim in Baden-Württemberg (Wahl \& Höhn 1988) and at Rosheim 'SainteOdile' in Alsace (Nickel 1997). It is, however, mostly in contemporary enclosure ditches, with their large numbers of human remains (Nickel 1997), that unequivocal evidence of violent treatment has been observed. Skulls from the same culture, interpreted as trophies, have also been discovered at Ilsfeld and Bruchsal in Baden-Württemberg (Wahl 2007: 169_ 71 ; 2008). Wahl attributes these discoveries to acts of war, but other authors think that this interpretation fails to explain many other cases (Jeunesse 2012). Pits and enclosures must certainly be included for a more complete understanding of the extent and variety of violent practices during this period. To achieve that, future studies will have to incorporate the results of other contemporary research on the archaeology of violence and warfare (Martin et al. 2012; Schulting \& Fibiger 2012; Allen \& Jones 2014; Ralph 2014), as well as that from unique and challenging discoveries such as pit 157.

\section{References}

ALLEN, M.W. \& T.L. Jones (ed.). 2014. Violence and warfare among hunter-gatherers. Walnut Creek (CA): Left Coast.

Baray, L. \& B. Boulestin (ed.). 2010. Morts anormaux et sépultures bizarres. Les dépôts humains en fosses circulaires et en silos du Néolithique à l'àge du Fer (Collection Art, Archéologie \& Patrimoine). Dijon: Éditions universitaires de Dijon.

BEECHING, A. 1991. Sépultures, territoires et société dans le Chasséen méridional. L'exemple du Bassin rhodanien, in A. Beeching et al. (ed.) Identité du Chasséen. Actes du colloque international de Nemours, 1989 (Mémoires du musée de Préhistoire d'Île-de-France 4): 327-41. Nemours: APRAIF.

BONNET, A. 1899. Die steinzeitliche Ansiedlung auf dem Michelsberge bei Untergrombach. Veröffentlichungen der Grossherzoglich Badischen Sammlungen für Altertums- und Völkerkunde in Karlsrube und des Karlsruher Altertumsvereins für dessen Mitglieder Zwangloses 2: 39-54.

Boulestin, B. 1999. Approche taphonomique des restes humains. Le cas des Mésolithiques de la grotte des Perrats et le problème du cannibalisme en préhistoire récente européenne (British Archaeology Reports international series 776). Oxford: Archaeopress.
- 2008. Pourquoi mourir ensemble? À propos des tombes multiples dans le Néolithique français. Bulletin de la Société préhistorique française 105: 103-30.

CRUBÉZY, E.1991. Les pratiques funciété préhistorique françaisehiquyenne vallée du Rhône, in A. Beeching et al. (ed.) Identitg ng s funciété préhistorique françaisehiquyenne vallée du Rhôn (Mntitg ng s funciété préhistorique françaisehiquye): 393-98. Nemours: APRAIF.

JEUNESSE, C. 2010. Les sépultures en fosses circulaires de l'horizon 4500-3500: contribution à l'étude comparée des systèmes funéraires du Néolithique européen, in L. Baray \& B. Boulestin (ed.) Morts anormaux et sépultures bizarres. Les dépôts humains en fosses circulaires et en silos du Néolithique à l'àge du Fer (Collection Art, Archéologie \& Patrimoine): 28-48. Dijon: Éditions universitaires de Dijon.

- 2012. A propos des crânes découverts dans les fossés d'enceintes de la culture de Michelsberg, in B. Boulestin \& D. Henry-Gambier (ed.) Crânes trophées, crânes d'ancêtres et autres pratiques autour de la tête: problèmes d'interprétation en archéologie (British Archaeology Reports international series 2415): 99-105. Oxford: Archaeopress.

KNOWLES, N. 1940. The torture of captives by the Indians of eastern North America. Proceedings of the American Philosophical Society 82: 151-225.

(C) Antiquity Publications Ltd, 2015 
Lefranc, P., A. Denaire, F. Chenal \& R.-M. Arbogast. 2010. Les inhumations et les dépôts d'animaux en fosses circulaires du Néolithique récent du sud de la plaine du Rhin supérieur. Gallia Préhistoire 52: 61-116.

LeFranc, P., R.-M. Arbogast, F. Chenal, E. Hildbrand, M. Merki, C. Strahm, S. van WilligEN \& M. WOrRLE. 2012. Inhumations, dépôts d'animaux et perles en cuivre du IV millénaire sur le site néolithique récent de Colmar 'Aérodrome' (Haut-Rhin). Bulletin de la Société préhistorique française 109: 689-730.

Le Moyne, J. 1875. Narrative of Le Moyne, an artist who accompanied the French expedition to Florida under Laudonnière, 1564. Boston (MA): James R. Osgood \& Company.

LICHARDUS, J. 1986. Le rituel funéraire de la culture de Michelsberg dans la région du Rhin supérieur et moyen, in J.-P. Demoule \& J. Guilaine (ed.) Le Néolithique de la France. Hommage à Gérard Bailloud: 343-58. Paris: Picard.

MACLEOD, W.C. 1929. The origin of servile labor groups. American Anthropologist (new series) 31: 89-113.

Martin, D.L., R.P. Harrod \& V.R. Pérez (ed.). 2012. The bioarchaeology of violence. Gainesville: University Press of Florida.

MensforTh, R.P. 2007. Human trophy taking in eastern North America during the Archaic Period. The relationship to warfare and social complexity, in R.J. Chacon \& D.H. Dye (ed.) The taking and displaying of human body parts as trophies by Amerindians: 222-77. New York: Springer.

Murail, P., J. BruzeK, F. HouËt \& E. Cunha. 2005. DSP: a tool for probabilistic sex diagnosis using worldwide variability in hip-bone measurements. Bulletins et mémoires de la Société d'anthropologie de Paris nouvelle série 17: 167-76.

NiCKEL, C. 1997. Menschliche Skelettreste aus Michelsberger Fundzusammenhängen: Zur Interpretation einer Fundgattung. Bericht der Römisch-Germanischen Kommission 78: 29-195.

RALPH, S. (ed.). 2014. The archaeology of violence: interdisciplinary approaches. Albany: State University of New York Press.
SCHEUer, L. \& S. Black. 2000. Developmental juvenile osteology. London: Academic.

SCHMITT, A. 2005. Une nouvelle méthode pour estimer l'âge au décès des adultes à partir de la surface sacro-pelvienne iliaque. Bulletins et mémoires de la Société d'anthropologie de Paris (nouvelle série) 17: 89-101.

SChulting, R. \& L. Fibiger (ed.). 2012. Sticks, stones, \& broken bones: Neolithic violence in a European perspective. Oxford: Oxford University Press.

SCHWEITZER, J. 1987. Le site Michelsberg de Didenheim. Cahiers de l'Association pour la promotion de la recherche archéologique en Alsace 3: 50-87.

TESTART, A. 2004. Les morts d'accompagnement. La servitude volontaire I. Paris: Éditions Errance.

- (ed.). 2012. Les armes dans les eaux. Questions d'interprétation en archéologie. Paris: Éditions Errance.

Testart, A., C. Jeunesse, L. Baray \& B. Boulestin. 2010. Les esclaves des tombes néolithiques. Pour la Science 396: 74-80.

UBELAKER, D.H. 1989. Human skeletal remains: excavation, analysis, interpretation (Manuals on Archeology 2). Washington, D.C.: Taraxacum.

Villa, P. \& E. MAHIEU. 1991. Breakage patterns of human long bones. Journal of Human Evolution 21 27-48.

WaHL, J. 2007. Karies, Kampf und Schädelkult. 150 Jahre anthropologische Forschung in Südwestdeutschland. Stuttgart: Konrad Theiss.

- 2008. Profan oder kultisch-bestattet oder entsorgt ? Die menschlichen Skelettreste aus den Michelsberger Erdwerken von Heilbronn-Klingenberg, Neckarsulm-Obereisesheim und Ilsfeld, in U. Seidel (ed.) Michelsberger Erdwerke im Raum Heilbronn-Neckarsulm-Obereisesheim 'Hetzenberg', Ilsfeld 'Ebene', Lkr. Heilbronn, und Heilbronn-Klingenberg 'Schloßberg', Stadtkr. Heilbronn (Materialhefte zur Archäologie in Baden-Württemberg 81/3): 703-848. Stuttgart: Konrad Theiss.

WAHL, J. \& B. HÖHN. 1988. Eine Mehrfachbestattung der Michelsberger Kultur aus Heidelberg-Handschuhsheim, Rhein-Neckar-Kreis. Fundberichte aus Baden-Württemberg 13: 123-98.

Received: 30 September 2014; Accepted: 15 January 2015; Revised: 19 January 2015

(C) Antiquity Publications Ltd, 2015 